University of Wollongong

Research Online

Australian Institute for Innovative Materials -

Papers

Australian Institute for Innovative Materials

$1-1-2013$

\title{
A facile route to synthesize transition metal oxide/reduced graphene oxide composites and their lithium storage performance
}

Chongjun Zhao

East China University of Science and Technology

Shulei Chou

University of Wollongong, shulei@uow.edu.au

Yunxiao Wang

University of Wollongong, yw708@uowmail.edu.au

Cuifeng Zhou

University Of Sydney

Hua-Kun Liu

University of Wollongong, hua@uow.edu.au

See next page for additional authors

Follow this and additional works at: https://ro.uow.edu.au/aiimpapers

Part of the Engineering Commons, and the Physical Sciences and Mathematics Commons

Research Online is the open access institutional repository for the University of Wollongong. For further information contact the UOW Library: research-pubs@uow.edu.au 


\title{
A facile route to synthesize transition metal oxide/reduced graphene oxide composites and their lithium storage performance
}

\begin{abstract}
Transition metal oxide (Mn304, Fe2O3, $\mathrm{Co304}$, and $\mathrm{ZnO}$ ) and reduced graphene oxide (RGO) composites were successfully synthesized via a hydrothermal method using the direct reaction between the corresponding metal powder and graphene oxide (GO). In this process, the $\mathrm{GO}$ can be reduced by transition metal powder in water, and the nanosized metal oxide can be obtained, and homogeneously mixed with and wrapped by RGO to form a metal oxide/RGO composite at the same time. X-ray diffraction, Raman spectroscopy, X-ray photoelectron spectroscopy, and scanning and transmission electron microscopy were used to characterize the as-prepared materials. The different experimental parameters, including reactants, solvents, atmosphere inside the autoclave, temperature, and reaction time, were investigated for their effects on the phase of the products. Furthermore, as an example, the lithium storage properties of $\mathrm{Fe} 2 \mathrm{O} 3 / \mathrm{RGO}$ and $\mathrm{Co304/RGO}$ composites were also investigated. The electrochemical performance shows both good cycling stability ( $852 \mathrm{~mA} \mathrm{~h} \mathrm{g-1} \mathrm{up} \mathrm{to} 200$ cycles) and high rate capability ( $425 \mathrm{~mA} \mathrm{~h} \mathrm{g-1}$ at the $4 \mathrm{C}$ rate). This can be attributed to the novel RGO-wrapped composite structure, which can buffer the volume changes and maintain good electrical conductivity.
\end{abstract}

\section{Keywords}

reduced, graphene, composites, their, lithium, storage, performance, synthesize, transition, facile, metal, route, oxide

Disciplines

Engineering | Physical Sciences and Mathematics

\section{Publication Details}

Zhao, C., Chou, S., Wang, Y., Zhou, C., Liu, H. K. and Dou, S. X. (2013). A facile route to synthesize transition metal oxide/reduced graphene oxide composites and their lithium storage performance. RSC Advances, 3 (37), 16597-16603.

\section{Authors}

Chongjun Zhao, Shulei Chou, Yunxiao Wang, Cuifeng Zhou, Hua-Kun Liu, and S X. Dou 
Cite this: RSC Advances, 2013, 3, 16597

Received 25th April 2013,

Accepted 4th July 2013

DOI: $10.1039 / c 3 r a 42044 b$

www.rsc.org/advances

\section{A facile route to synthesize transition metal oxide/ reduced graphene oxide composites and their lithium storage performance $\dagger$}

\author{
Chongjun Zhao, ${ }^{\text {abd }}$ Shu-Lei Chou, ${ }^{\text {a a }}$ Yunxiao Wang, ${ }^{a}$ Cuifeng Zhou, ${ }^{c}$ Hua-Kun Liu ${ }^{\text {ad }}$ \\ and Shi-Xue Dou ${ }^{a}$
}

\begin{abstract}
Transition metal oxide $\left(\mathrm{Mn}_{3} \mathrm{O}_{4}, \mathrm{Fe}_{2} \mathrm{O}_{3}, \mathrm{CO}_{3} \mathrm{O}_{4}\right.$, and $\left.\mathrm{ZnO}\right)$ and reduced graphene oxide (RGO) composites were successfully synthesized via a hydrothermal method using the direct reaction between the corresponding metal powder and graphene oxide (GO). In this process, the GO can be reduced by transition metal powder in water, and the nanosized metal oxide can be obtained, and homogeneously mixed with and wrapped by RGO to form a metal oxide/RGO composite at the same time. X-ray diffraction, Raman spectroscopy, X-ray photoelectron spectroscopy, and scanning and transmission electron microscopy were used to characterize the as-prepared materials. The different experimental parameters, including reactants, solvents, atmosphere inside the autoclave, temperature, and reaction time, were investigated for their effects on the phase of the products. Furthermore, as an example, the lithium storage properties of $\mathrm{Fe}_{2} \mathrm{O}_{3} / \mathrm{RGO}$ and $\mathrm{CO}_{3} \mathrm{O}_{4} / \mathrm{RGO}$ composites were also investigated. The electrochemical performance shows both good cycling stability ( $~ 852 \mathrm{~mA} \mathrm{~h} \mathrm{~g}^{-1}$ up to 200 cycles) and high rate capability ( $425 \mathrm{~mA} \mathrm{~h} \mathrm{~g}^{-1}$ at the $4 \mathrm{C}$ rate). This can be attributed to the novel RGO-wrapped composite structure, which can buffer the volume changes and maintain good electrical conductivity.
\end{abstract}

\section{Introduction}

Composites of transition metal oxide (MO) and graphene are of great research interest, since they combine the properties of graphene and of the transition-metal oxide. Recently, they have found a broad range of applications in fields such as energy storage in supercapacitors ${ }^{1}$ and $\mathrm{Li}$ ion batteries, ${ }^{2}$ energy conversion, ${ }^{3}$ gas sensing, ${ }^{4}$ and photocatalysis. $^{5}$ Therefore, the preparation and application of $\mathrm{MO} /$ graphene composite materials has become a highly topical area. Until now, however, $\mathrm{MO} /$ graphene composite has been routinely prepared using the metal salt or compound, sometimes with the involvement of additional reducing agents, including both

\footnotetext{
${ }^{a}$ Institute for Superconducting and Electronic Materials, University of Wollongong, Wollongong, NSW 2522, Australia. E-mail: shulei@uow.edu.au; Fax: 6124221 5731; Tel: 61242981405

${ }^{b}$ Key Laboratory for Ultrafine Materials of Ministry of Education, Shanghai Key Laboratory of Advanced Polymeric Materials, School of Materials Science and Engineering, East China University of Science and Technology, Shanghai 200237, PR China. E-mail: chongjunzhao@ecust.edu.cn; Fax: 86216425 0838; Tel: 86216425 0838

'Australian Centre for Microscopy and Microanalysis, The University of Sydney, NSW 2006, Australia

${ }^{d}$ ARC Center of Excellence for Electromaterials Science, University of Wollongong, Wollongong, NSW 2522, Australia

$\dagger$ Electronic supplementary information (ESI) available: Information regarding the SEM of raw metal powder, XRD of products from different conditions, and AFM of GO. See DOI: 10.1039/c3ra42044b
}

toxic and hazardous materials (hydrazine ${ }^{6-10}$ or $\mathrm{NaBH}_{4}{ }^{11}$ ) and some eco-friendly chemical agents (glucose ${ }^{12}$ or ascorbic acid $\left.^{13}\right)$. Recently, $\mathrm{Fe}, \mathrm{Al}$, and $\mathrm{Zn}$ in the form of active metals were chosen to reduce graphene oxide (GO) to reduced GO (RGO) under different $\mathrm{pH}$ values in acid or basic conditions. ${ }^{14-18}$ As a result, high conductivity RGO was obtained in both cases. Because of the presence of large amounts of $\mathrm{HCl}$ or $\mathrm{H}_{2} \mathrm{SO}_{4}$, the product is only RGO. Therefore, this method is not suitable to produce metal oxide/graphene composites. There is still no report on the preparation of MO/RGO composite by direct reaction of metal and graphene oxide.

Here, we report the preparation of MO/RGO composites by directly reacting metal powder with GO by hydrothermal treatment in water, without using any additional reducing agent or solvent. The major merits of this method include: (1) it is a simple and green method that only involves mixing metal powder and GO suspension in water under hydrothermal conditions; (2) there are no side products and no impurities from the reducing agent; (3) this method is easy to scale up.

\section{Experimental section}

\section{Preparation of graphene oxide (GO)}

Graphite oxide was first synthesized using a modified Hummers' method according to Xu et al. ${ }^{19}$ Briefly, natural 
graphite powder $(3 \mathrm{~g})$ was put into an $80{ }^{\circ} \mathrm{C}$ solution of concentrated $\mathrm{H}_{2} \mathrm{SO}_{4}(12 \mathrm{~mL}), \mathrm{K}_{2} \mathrm{~S}_{2} \mathrm{O}_{8}(2.5 \mathrm{~g})$, and $\mathrm{P}_{2} \mathrm{O}_{5}(2.5 \mathrm{~g})$, and then kept for $4.5 \mathrm{~h}$ to pre-oxidize the graphite powder. After cooling to room temperature, $0.5 \mathrm{~L}$ de-ionized (DI) water was added into the mixture, which was left overnight. Subsequently, the dried pre-oxidized graphite collected from the mixture was oxidized by Hummer's method: Firstly, the pre-treated graphite powder was put into concentrated $\mathrm{H}_{2} \mathrm{SO}_{4}$ $\left(120 \mathrm{~mL}, 0{ }^{\circ} \mathrm{C}\right)$, followed by gradually adding $\mathrm{KMnO}_{4}$ under stirring at a controlled temperature below $20{ }^{\circ} \mathrm{C}$. Successively, the mixture was stirred at $35{ }^{\circ} \mathrm{C}$ for $2 \mathrm{~h}$, and then diluted with DI water $(250 \mathrm{~mL})$. After stirring for $2 \mathrm{~h}$, an additional $0.7 \mathrm{~L} \mathrm{DI}$ water was added, and shortly, $20 \mathrm{~mL} 30 \% \mathrm{H}_{2} \mathrm{O}_{2}$ was added. Lastly, the mixture was filtered and washed with $1: 10 \mathrm{HCl}$ aqueous solution $(1.5 \mathrm{~L})$ to remove metal ions, followed by a washing with DI water. Dialysis was carried out to further remove the remaining metal species.

The graphite oxide dispersion $\left(5 \mathrm{mg} \mathrm{mL}^{-1}\right)$ was sonicated under ambient conditions for $1.5 \mathrm{~h}$. The resultant homogeneous brown GO dispersion was obtained, which is stable for several months. In order to confirm the number of layers of the GO, atomic force microscope (AFM) measurements (Fig. S1 in the ESI $\dagger$ ) were performed after ultrasonication. Fig. S1, ESI $\dagger$ shows AFM images of the single layer graphene oxide (GO). The thickness of single-layer GO is $1.1 \pm 0.2 \mathrm{~nm}$, as previously reported, ${ }^{20}$ which is in good agreement with our results.

\section{Preparation of MO/RGO}

Synthesis of MO/RGO was achieved through the reaction between GO and the metal powder in a hydrothermal (solvothermal) environment. Zn powder (Sigma), Fe powder (Alfa Aesar), Mn powder (Aldrich), and Co powder (Alfa Aesar) were used here, respectively. Typically, $6 \mathrm{~mL}$ GO solution $(5 \mathrm{mg}$ $\mathrm{mL}^{-1}$ ) was diluted to $50 \mathrm{ml}$ first, and then $1 \mathrm{mmol}$ metal powder was added into the diluted GO solution under stirring. After 1-2 min, the transparent GO solution became turbid. Then, the mixture was further stirred for $5 \mathrm{~min}$ and transferred into a Teflon-lined autoclave, where it was heated at an appropriate temperature $\left(150{ }^{\circ} \mathrm{C}\right.$ for $\mathrm{Mn}, \mathrm{Fe}$, and $\mathrm{Zn}, 200{ }^{\circ} \mathrm{C}$ for Co) for $24 \mathrm{~h}$. The products were collected, filtered, washed with DI water and ethanol several times, and then dried.

\section{Characterization}

$\mathrm{X}$-ray diffraction (XRD) patterns were obtained by using a GBC MMA X-ray diffractometer with $\mathrm{Cu}-\mathrm{K} \alpha$ radiation $(\lambda=$ $1.54059 \AA$ ). Raman spectroscopy (Horiba Jobin Yvon/Lab RAM HR) was performed using a $632.81 \mathrm{~nm}$ He-Ne laser beam. Atomic force microscopy (AFM) was performed using an Asylum Research MFP-3D AFM system in tapping mode in air at room temperature. X-ray photoelectron spectroscopy (XPS, PHOIBOS 100 hemispherical analyzer, SPECS GmbH) was conducted with a pass energy of $26.00 \mathrm{eV}, 45^{\circ}$ take-off angle, and a beam size of $100 \mu \mathrm{m}$. The morphology and structure of samples were examined by scanning electron microscope (SEM; JSM 7500F, JEOL) and transmission electron microscope (TEM; JEM 2010, JEOL). Thermogravimetric analysis (TGA)/ differential scanning calorimetry (DSC) was performed in air using a Mettler-Toledo TGA/DSC 1 Share System from 60-900 ${ }^{\circ} \mathrm{C}$ at $5{ }^{\circ} \mathrm{C} \min ^{-1}$. Specific surface area was measured by the
Brunauer-Emmett-Teller (BET) method using a Micromeritics ASAP 2020.

\section{Electrochemical performance of MO/RGO}

To test the electrochemical performance, $\mathrm{Fe}_{2} \mathrm{O}_{3} / \mathrm{RGO}$ and $\mathrm{Co}_{3} \mathrm{O}_{4}$ composites were mixed with acetylene black (AB) and a binder (polyvinylidene difluoride (PVDF, Aldrich)) in a weight ratio of $80: 10: 10$ in $N$-methyl-2-pyrrolidone (NMP). The slurry was uniformly pasted onto pieces of $\mathrm{Cu}$ foil with an area of $1 \mathrm{~cm}^{2}$. Such prepared electrode sheets were dried at $120{ }^{\circ} \mathrm{C}$ in a vacuum oven for $12 \mathrm{~h}$. The electrochemical cells (CR 2032 coin-type cell) contained the composite on $\mathrm{Cu}$ foil as the working electrode, $\mathrm{Li}$ foil as the counter electrode and reference electrode, a porous polypropylene film as separator, and $1 \mathrm{M} \mathrm{LiPF}_{6}$ (battery grade 99.99\%, Aldrich) in a $1: 2(\mathrm{v} / \mathrm{v})$ mixture of ethylene carbonate (EC, anhydrous 99\%, SigmaAldrich) and diethyl carbonate (DEC, anhydrous 99+ \%, SigmaAldrich) as the electrolyte. The cells were assembled in an Arfilled glove box. The cells were cycled at a current density of $200 \mathrm{~mA} \mathrm{~g}^{-1}$ or cycled at different current densities between 0.01 and $3.0 \mathrm{~V}$ using a computer-controlled charger system manufactured by Land Battery Testers. The specific capacity is based on the weight of the composites. The active materials loading rate is around $5 \mathrm{mg} \mathrm{cm}^{-2}$.

\section{Results and discussion}

\section{Characterization}

Fig. 1 shows SEM images of as-prepared pure phase MO/RGO composites. Two types of morphologies, including nanoparticles from the MO and wrinkled sheet-like structures from the RGO, can be observed. The metal oxide nanoparticles are mixed very well with and wrapped by the sheet-like RGO. The particle size distribution of the $\mathrm{MO}$ is fairly narrow, with average particle size of $50.9\left(\mathrm{Mn}_{3} \mathrm{O}_{4} / \mathrm{RGO}\right), 59.5\left(\mathrm{Fe}_{2} \mathrm{O}_{3} / \mathrm{RGO}\right)$, $69.8\left(\mathrm{Co}_{3} \mathrm{O}_{4} / \mathrm{RGO}\right)$, and $108.3(\mathrm{ZnO} / \mathrm{RGO}) \mathrm{nm}$. The metal oxide

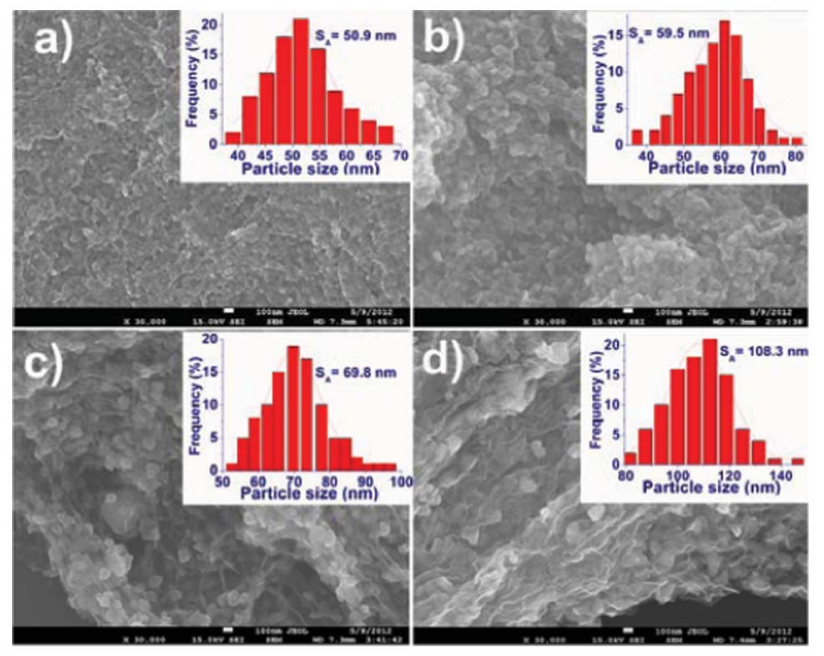

Fig. 1 SEM images of $\mathrm{Mn}_{3} \mathrm{O}_{4} / \mathrm{RGO}$ (a), $\mathrm{Fe}_{2} \mathrm{O}_{3} / \mathrm{RGO}$ (b), $\mathrm{CO}_{3} \mathrm{O}_{4} / \mathrm{RGO}$ (c), and $\mathrm{ZnO} / \mathrm{RGO}$ (d) nanocomposites. The insets are the particle size distributions. 


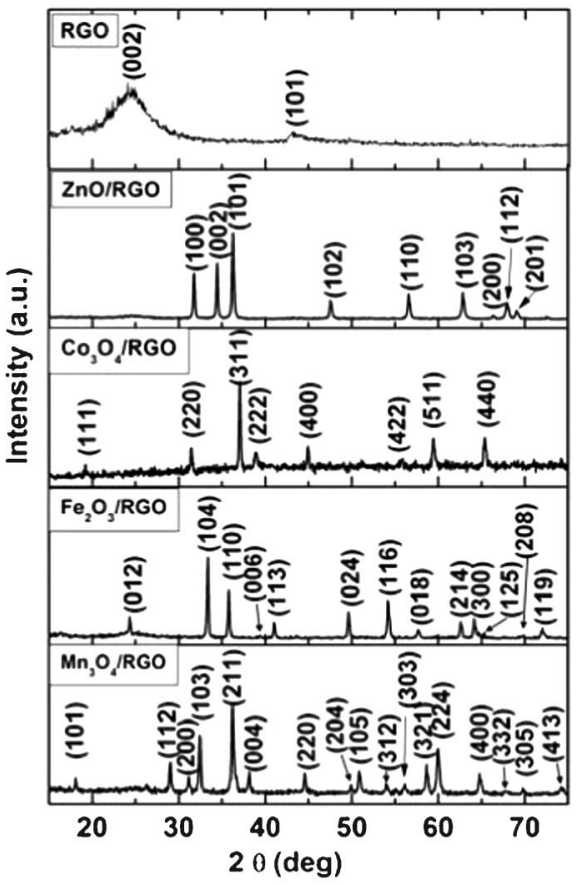

Fig. 2 XRD patterns of the RGO and the metal oxide/RGO composites.

nanoparticles are much smaller than those of the metal powder precursor (see ESI, † Fig. S2 and S3). The RGO will also prevent the further growth of the MO particles.

$\mathrm{X}$-ray diffraction (XRD) was used to confirm the phase of the MO in the as-prepared composites. Fig. 2 shows the XRD patterns of pure RGO and of different $\mathrm{MO}$ and RGO composites. The XRD pattern of RGO shows a broad peak at $24.5^{\circ}(002)$ and a less intense peak at $43.3^{\circ}$ (101). Both of these two peaks indicate the layered structure of RGO. The broad diffraction band indicates an interlayer spacing of graphene of $0.36 \mathrm{~nm}$, which is slightly larger than the interlayer separation in graphite of $0.34 \mathrm{~nm}$. This also suggests the incomplete restoration of the graphite crystal structure.

The XRD pattern of $\mathrm{Mn}_{3} \mathrm{O}_{4} / \mathrm{RGO}$ can be indexed to a tetrahedral phase with space group I41/amd and lattice constants $a=5.7453 \AA$ and $c=9.4354 \AA$ (JCPDS no. 24-0734). The $\mathrm{Fe}_{2} \mathrm{O}_{3} / \mathrm{RGO}$ composite contains a rhombohedral phase of $\alpha-\mathrm{Fe}_{2} \mathrm{O}_{3}$ with space group $R \overline{3} c$ and lattice constants $a=$ $5.0166 \AA$ and $c=13.7197 \AA$ (JCPDS no. 33-0664). The XRD pattern of $\mathrm{Co}_{3} \mathrm{O}_{4} / \mathrm{RGO}$ can be matched very well with a cubic phase of $\mathrm{Co}_{3} \mathrm{O}_{4}$ with space group $\mathrm{Fd}-3 \mathrm{~m}$ and lattice constant $a$ $=8.0561 \AA$ (JCPDS no. 65-3103). The ZnO/RGO composite is composed of a hexagonal $\mathrm{ZnO}$ phase with space group P63mc and lattice constants $a=3.2428 \AA$ and $c=5.1924 \AA$ (JCPDS no. 36-1451). No peaks of any other phases were detected, indicating the high purity of the metal oxide structures. Due to the high XRD intensity of the transition metal oxides and the broad peak of RGO, the peak from RGO is very hard to distinguish.

Raman spectroscopy was used to further confirm the presence of RGO and metal oxide in the composites. The RGO shows two main bands at 1326.4 and $1602.3 \mathrm{~cm}^{-1}$,

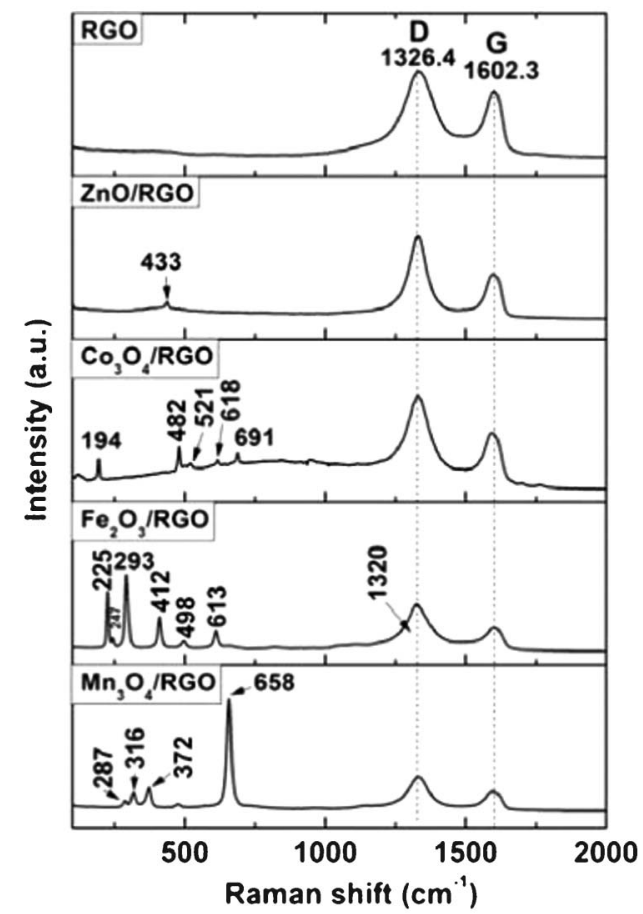

Fig. 3 Raman spectra of RGO and MO/RGO nanocomposites.

corresponding to the D and G bands, respectively. ${ }^{21,22}$ The D and $\mathrm{G}$ bands were also observed in the MO/RGO composites, indicating the presence of RGO. The intensity ratio $\left(I_{\mathrm{D}} / I_{\mathrm{G}}\right)$ of the $\mathrm{D}$ band to the $\mathrm{G}$ band of RGO is about 1.34, in good agreement with previous reports. ${ }^{23-25}$ The $I_{\mathrm{D}} / I_{\mathrm{G}}$ ratios of the composites are $1.58\left(\mathrm{Mn}_{3} \mathrm{O}_{4}\right), 2.29\left(\mathrm{Fe}_{2} \mathrm{O}_{3}\right), 1.63\left(\mathrm{Co}_{3} \mathrm{O}_{4}\right)$, and $1.89(\mathrm{ZnO})$. The composites show higher $I_{\mathrm{D}} / I_{\mathrm{G}}$ ratios due to the presence of unrepaired defects that remained after the removal of large amounts of oxygen-containing functional groups. The highest one is from $\mathrm{Fe}_{2} \mathrm{O}_{3} / \mathrm{RGO}$ composite because $\mathrm{Fe}_{2} \mathrm{O}_{3}$ has a Raman active band at $1320 \mathrm{~cm}^{-1}$. In addition, $\mathrm{Fe}_{2} \mathrm{O}_{3} / \mathrm{RGO}$ composite shows seven peaks in the Raman spectrum, namely, two $A_{1 \mathrm{~g}}$ modes (225 and $498 \mathrm{~cm}^{-1}$ ) and five $\mathrm{E}_{\mathrm{g}}$ modes $\left(247,293,299,412\right.$, and $\left.613 \mathrm{~cm}^{-1}\right)$, in good agreement with ref. 26. In Fig. 3, the presence of $\mathrm{Mn}_{3} \mathrm{O}_{4}$ is also confirmed by Raman spectroscopy, with a strong peak at 658 $\mathrm{cm}^{-1}$, and three small peaks at 287,316 , and $327 \mathrm{~cm}^{-1}$, which are the typical Raman peaks of $\mathrm{Mn}_{3} \mathrm{O}_{4}$ reported in the literature. ${ }^{27}$ The Raman spectrum of $\mathrm{Co}_{3} \mathrm{O}_{4} / \mathrm{RGO}$ contains five Raman active peaks at $194\left(\mathrm{~F}_{2 \mathrm{~g}}\right), 482\left(\mathrm{~A}_{1 \mathrm{~g}}\right), 521\left(\mathrm{~F}_{2 \mathrm{~g}}\right), 618\left(\mathrm{~F}_{2 \mathrm{~g}}\right)$, and $691\left(\mathrm{E}_{\mathrm{g}}\right) \mathrm{cm}^{-1}$, confirming the structure of $\mathrm{Co}_{3} \mathrm{O}_{4} \cdot{ }^{28}$ In the Raman spectrum of $\mathrm{ZnO} / \mathrm{RGO}$ composite, the one dominant sharp peak at $432.7 \mathrm{~cm}^{-1}$ can be attributed to the $\mathrm{E}_{2}$ mode of $\mathrm{ZnO}$ nanoparticles. This is also characteristic of hexagonal phase ZnO. ${ }^{29}$

The composites were further examined using X-ray photoelectron spectroscopy (XPS), as shown in Fig. 4. CasaXPS processing software was used to fit the spectra. The fitted C 1s spectra of the composites are similar, showing three typical peaks centred at $284.5,285.6$, and $288.4 \mathrm{eV}$, corresponding to the $\mathrm{C}=\mathrm{C} / \mathrm{C}-\mathrm{C}, \mathrm{C}-\mathrm{O} / \mathrm{C}=\mathrm{O}$, and $\mathrm{O}-\mathrm{C}=\mathrm{O}$ functionalities, respectively. ${ }^{15}$ The low intensity of the peaks at 285.6 and $288.4 \mathrm{eV}$ 

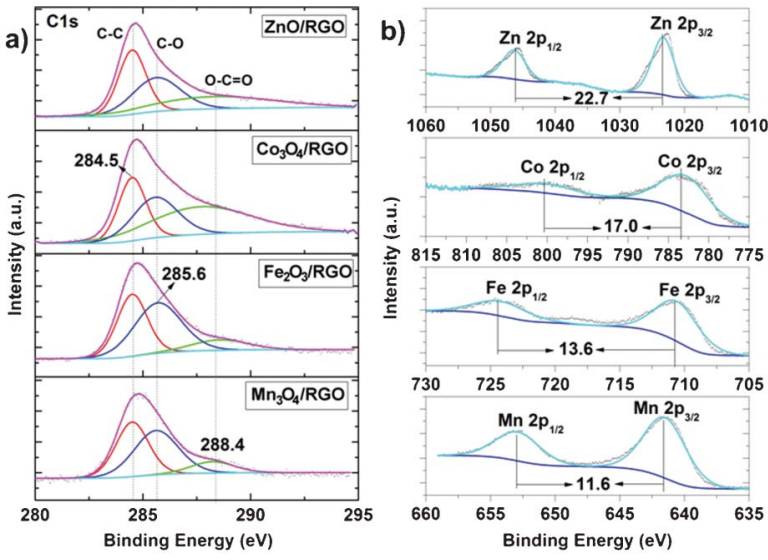

Fig. 4 XPS spectra of MO/RGO nanocomposites for C1s (a) and 2p peaks of transition metal (b).

indicates the removal of oxygen functional groups. The presence and chemical valence of the transition metal oxide in the composites were also confirmed by the XPS measurements (Fig. 4(b)). The $2 \mathrm{p}_{3 / 2}$ binding energy and the separation between $2 \mathrm{p}_{1 / 2}$ and $2 \mathrm{p}_{3 / 2}$ (in brackets) are 641.6 (11.6), 711.0 (13.6), 783.45 (17.0), and 1023.4 (22.7) eV for Mn, Fe, Co, and $\mathrm{Zn}$ in the composites, respectively. These numbers all matched very well with the values reported for $\mathrm{Mn}_{3} \mathrm{O}_{4}, \alpha-\mathrm{Fe}_{2} \mathrm{O}_{3}, \mathrm{Co}_{3} \mathrm{O}_{4}$, and $\mathrm{ZnO}$ in a standard XPS handbook. ${ }^{30}$

High resolution transmission electron microscope (HRTEM) images are shown in Fig. 5(a-d). Lattice fringes with sizes of $0.31,0.27,0.24$, and $0.25 \mathrm{~nm}$ can be indexed to the (112) plane in $\mathrm{Mn}_{3} \mathrm{O}_{4}$, the (104) plane in $\mathrm{Fe}_{2} \mathrm{O}_{3}$, the (311) plane in $\mathrm{Co}_{3} \mathrm{O}_{4}$, and the (101) plane in $\mathrm{ZnO}$, respectively. The crystal size is in the order $\mathrm{ZnO} / \mathrm{RGO}(\sim 80 \mathrm{~nm})>\mathrm{Fe}_{2} \mathrm{O}_{3} / \mathrm{RGO}(\sim 50 \mathrm{~nm})>$
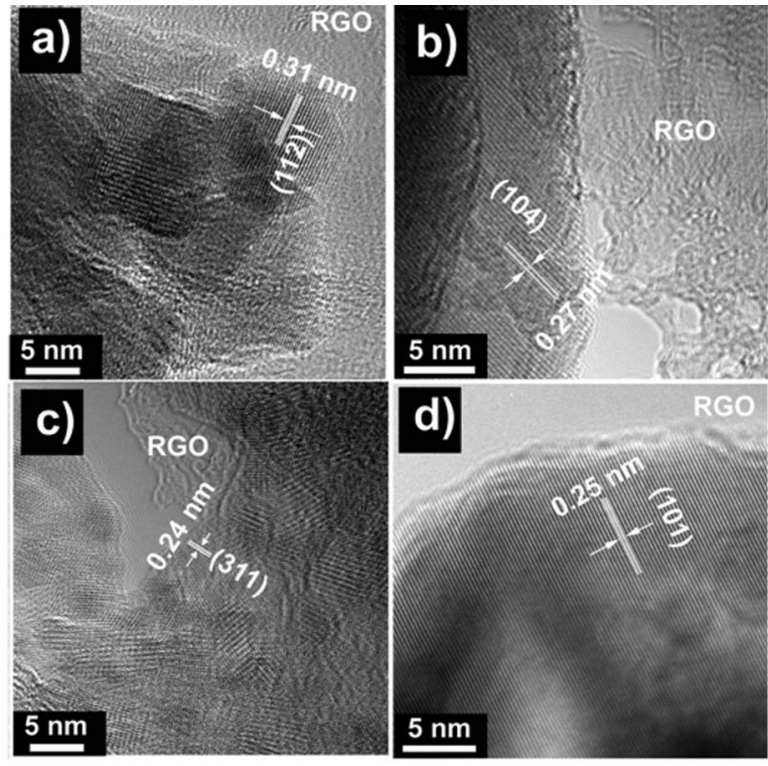

Fig. 5 HRTEM images of $\mathrm{Mn}_{3} \mathrm{O}_{4} / \mathrm{RGO}$ (a), $\mathrm{Fe}_{2} \mathrm{O}_{3} / \mathrm{RGO}$ (b), $\mathrm{CO}_{3} \mathrm{O}_{4} / \mathrm{RGO}$ (c), and $\mathrm{ZnO} / \mathrm{RGO}(\mathrm{d})$ composites.

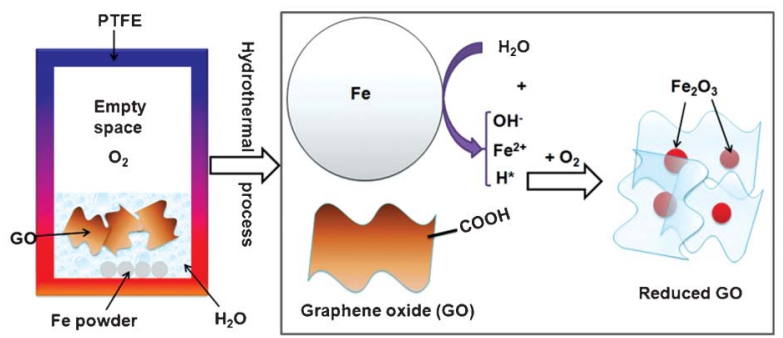

Fig. 6 Schematic diagram of hydrothermal process to prepare metal oxide/RGO composites. PTFE refers to the polytetrafluoroethylene (Teflon ${ }^{\mathbb{R}}$ ) liner of the autoclave.

$\mathrm{Mn}_{3} \mathrm{O}_{4} / \mathrm{RGO}(\sim 10 \mathrm{~nm})>\mathrm{Co}_{3} \mathrm{O}_{4} / \mathrm{RGO}(\sim 5 \mathrm{~nm})$. The observation of RGO in HRTEM is fairly difficult, due to the fact that the RGO can change its morphology or decompose under high energy electrons. Therefore, we only can observe some typical porous carbon-like structure after finishing the HRTEM focus adjustment.

\section{Reaction mechanism}

The reaction mechanism was investigated further by changing the different experimental parameters, including reactants, solvents, atmosphere inside of the autoclave, temperature, and reaction time. A schematic drawing of the hydrothermal process to prepare metal oxide/RGO composites is shown in Fig. 6.

The experimental details and XRD results are summarized in Table 1. The XRD patterns are shown in the ESI, † Fig. S4-S6. Without adding GO (Samples \#22-24), the products are mixtures of the metal and the metal oxide. The metal powder could partially be oxidized by $\mathrm{O}_{2}$, which was both dissolved in the water and present in the top empty part of the autoclave vessels. If we use $\mathrm{N}_{2}$ to eliminate the $\mathrm{O}_{2}$ (Samples \#12 and \#20), the product is also a mixture of metal, metal oxide, and RGO. For Sample \#12, the products of the reaction between $\mathrm{Fe}$ and GO are a mixture of Fe, $\mathrm{Fe}_{2} \mathrm{O}_{3}, \mathrm{Fe}_{3} \mathrm{O}_{4}$, and RGO, while Sample \#20 is a mixture of $\mathrm{Mn}, \mathrm{Mn}_{3} \mathrm{O}_{4}$, and $\mathrm{RGO}$ for the reaction between $\mathrm{Mn}$ and GO after bubbling $\mathrm{N}_{2}$ for $2 \mathrm{~h}$. Therefore, both the GO and the $\mathrm{O}_{2}$ in the top empty space and in the solution are acting as oxidation agents to react with the metal powder. Different solvents, including water, ethanol (Samples \#5, \#9, and \#17), and toluene (Sample \#13) were also used to investigate the solvent effect. When water was used, single phase $\mathrm{Fe}_{2} \mathrm{O}_{3}$ and RGO composite (Sample \#6) can be prepared after hydrothermal treatment at $150{ }^{\circ} \mathrm{C}$ for $24 \mathrm{~h}$. If we change the solvent from water to ethanol (Sample \#9) under the same hydrothermal conditions, only a mixture of metal and metal oxide phase can be obtained. Using toluene as solvent (Sample \#13), the only detectable phase is metal. Therefore, water also plays a very important role in the reaction. One of the possible reasons is that $\mathrm{H}_{2} \mathrm{O}$ acts as the medium for the reaction between GO and metal powder. In addition, GO is much easier to disperse in water. This will increase the probability of contact inside the autoclave between the GO and the metal particles. Temperature is also a crucial factor for the hydrothermal reaction. Pure phase metal oxide can only be 
Table 1 Experimental details for the preparation of metal oxide and reduced graphene oxide composites

\begin{tabular}{|c|c|c|c|c|c|c|c|}
\hline \multirow{2}{*}{ No. } & \multicolumn{3}{|l|}{ Reactants } & \multicolumn{3}{|c|}{ Conditions } & \multirow{2}{*}{$\begin{array}{l}\text { Product } \\
\text { Composite }\end{array}$} \\
\hline & Metal powder & GO (mg) & Solvent & $T\left({ }^{\circ} \mathrm{C}\right)$ & $t(\mathrm{~h})$ & Gas inside vessel & \\
\hline 1 & Zn 1 mmol & 30 & $\mathrm{H}_{2} \mathrm{O}$ & 150 & 24 & Air & $\mathrm{ZnO} / \mathrm{RGO}$ \\
\hline 2 & & & $\mathrm{H}_{2} \mathrm{O}$ & 150 & 1 & Air & $\mathrm{ZnO} / \mathrm{RGO}$ \\
\hline 3 & & & $\mathrm{H}_{2} \mathrm{O}$ & 90 & 24 & Air & $\mathrm{ZnO} / \mathrm{RGO}$ \\
\hline 4 & & & $\mathrm{H}_{2} \mathrm{O}$ & 180 & 24 & Air & $\mathrm{ZnO} / \mathrm{RGO}$ \\
\hline 5 & & & EtOH & 150 & 24 & Air & $\mathrm{Zn} / \mathrm{ZnO} / \mathrm{RGO}$ \\
\hline 6 & Fe $1 \mathrm{mmol}$ & 30 & $\mathrm{H}_{2} \mathrm{O}$ & 150 & 24 & Air & $\mathrm{Fe}_{2} \mathrm{O}_{3} / \mathrm{RGO}$ \\
\hline 7 & & & $\mathrm{H}_{2} \mathrm{O}$ & 150 & 1 & Air & $\mathrm{Fe} / \mathrm{Fe} 3 \mathrm{O} 4 / \mathrm{Fe}_{2} \mathrm{O}_{3} / \mathrm{RGO}$ \\
\hline 8 & & & $\mathrm{H}_{2} \mathrm{O}$ & 90 & 24 & Air & $\mathrm{Fe} / \mathrm{Fe}_{2} \mathrm{O}_{3} / \mathrm{Fe}_{3} \mathrm{O}_{4} / \mathrm{RGO}$ \\
\hline 9 & & & EtOH & 150 & 24 & Air & $\mathrm{Fe} / \mathrm{Fe}_{2} \mathrm{O}_{3} / \mathrm{RGO}$ \\
\hline 10 & & & $\mathrm{H}_{2} \mathrm{O}$ & 180 & 24 & Air & $\mathrm{Fe}_{2} \mathrm{O}_{3} / \mathrm{Fe}_{3} \mathrm{O}_{4} / \mathrm{RGO}$ \\
\hline 11 & & & $\mathrm{H}_{2} \mathrm{O}$ & 200 & 24 & Air & $\mathrm{Fe}_{2} \mathrm{O}_{3} / \mathrm{Fe}_{3} \mathrm{O}_{4} / \mathrm{RGO}$ \\
\hline 12 & & & $\mathrm{H}_{2} \mathrm{O}$ & 150 & 24 & $\mathrm{~N}_{2} / \mathrm{vac}$ & $\mathrm{Fe} / \mathrm{Fe}_{2} \mathrm{O}_{3} / \mathrm{Fe}_{3} \mathrm{O}_{4} / \mathrm{RGO}$ \\
\hline 13 & & & Toluene & 150 & 24 & Air & $\mathrm{Fe} / \mathrm{RGO}$ \\
\hline 14 & Mn $1 \mathrm{mmol}$ & 30 & $\mathrm{H}_{2} \mathrm{O}$ & 150 & 24 & Air & $\mathrm{Mn}_{3} \mathrm{O}_{4} / \mathrm{RGO}$ \\
\hline 15 & & & $\mathrm{H}_{2} \mathrm{O}$ & 150 & 1 & Air & $\mathrm{Mn}_{3} \mathrm{O}_{4} / \mathrm{RGO}$ \\
\hline 16 & & & $\mathrm{H}_{2} \mathrm{O}$ & 90 & 24 & Air & $\mathrm{Mn}_{3} \mathrm{O}_{4} / \mathrm{RGO}$ \\
\hline 17 & & & EtOH & 150 & 24 & Air & $\mathrm{Mn} / \mathrm{Mn}_{3} \mathrm{O}_{4} / \mathrm{RGO}$ \\
\hline 18 & & & $\mathrm{H}_{2} \mathrm{O}$ & 180 & 24 & Air & $\mathrm{Mn}_{3} \mathrm{O}_{4} / \mathrm{RGO}$ \\
\hline 19 & & & $\mathrm{H}_{2} \mathrm{O}$ & 200 & 24 & Air & $\mathrm{Mn}_{3} \mathrm{O}_{4} / \mathrm{RGO}$ \\
\hline 20 & & & $\mathrm{H}_{2} \mathrm{O}$ & 150 & 24 & $\mathrm{~N}_{2} /$ vac & $\mathrm{Mn} / \mathrm{Mn}_{3} \mathrm{O}_{4} / \mathrm{RGO}$ \\
\hline 21 & Co $1 \mathrm{mmol}$ & 30 & $\mathrm{H}_{2} \mathrm{O}$ & 200 & 24 & Air & $\mathrm{Co}_{3} \mathrm{O}_{4} / \mathrm{RGO}$ \\
\hline 22 & $\mathrm{Zn}$ & 0 & $\mathrm{H}_{2} \mathrm{O}$ & 150 & 24 & Air & $\mathrm{Zn} / \mathrm{ZnO}$ \\
\hline 23 & $\mathrm{Fe}$ & 0 & $\mathrm{H}_{2} \mathrm{O}$ & 150 & 24 & Air & $\mathrm{Fe} / \mathrm{Fe}_{3} \mathrm{O}_{4}$ \\
\hline 24 & Mn & 0 & $\mathrm{H}_{2} \mathrm{O}$ & 150 & 24 & Air & $\mathrm{Mn} / \mathrm{Mn}_{3} \mathrm{O}_{4}$ \\
\hline
\end{tabular}

obtained with temperatures higher than $150{ }^{\circ} \mathrm{C}$. A longer reaction time $(24 \mathrm{~h})$ is also favourable to the formation of the pure phase metal oxide, but the particle size is also larger.

The possible reaction mechanism is proposed in Fig. 6.

Firstly, Fe could react with water under hydrothermal conditions to possibly yield hydrogen radicals $\left(\mathrm{H}^{*}\right)$ to reach an equilibrium state.

$$
\mathrm{Fe}+2 \mathrm{H}_{2} \mathrm{O} \leftrightarrow \mathrm{Fe}^{2+}+2 \mathrm{H}^{*}+2 \mathrm{OH}^{-}
$$

If there is $\mathrm{GO}$ and $\mathrm{O}_{2}$ inside the vessel, the hydrogen radicals can react with both $\mathrm{GO}$ and $\mathrm{O}_{2}$ to yield $\mathrm{RGO}$ and $\mathrm{H}_{2} \mathrm{O}$

$$
\begin{gathered}
\mathrm{GO}+\mathrm{H}^{*} \rightarrow \mathrm{RGO}+\mathrm{H}_{2} \mathrm{O} \\
\mathrm{O}_{2}+4 \mathrm{H}^{*} \rightarrow 2 \mathrm{H}_{2} \mathrm{O}
\end{gathered}
$$

Therefore, the equilibrium reaction of eqn (1) will move from left to right. Then, the Fe(II) can be further oxidized by $\mathrm{O}_{2}$ and reacts with $\mathrm{OH}^{-}$to form $\mathrm{Fe}_{2} \mathrm{O}_{3}$.

$$
6 \mathrm{Fe}^{2+}+\mathrm{O}_{2}+\mathrm{OH}^{-} \rightarrow \mathrm{Fe}_{2} \mathrm{O}_{3}+\mathrm{H}_{2} \mathrm{O}
$$

The simplified total reaction will be:

$$
\mathrm{Fe}+\mathrm{GO}+\mathrm{O}_{2}=\mathrm{Fe}_{2} \mathrm{O}_{3}+\mathrm{RGO}+\mathrm{H}_{2} \mathrm{O}
$$

\section{Electrochemical performance}

Lithium storage in $\mathrm{Fe}_{2} \mathrm{O}_{3} / \mathrm{RGO}$ composite was investigated. Fig. 7(a) shows the charge-discharge curves of $\mathrm{Fe}_{2} \mathrm{O}_{3} / \mathrm{RGO}$ composite electrodes in coin test cells between 0.01 and $3.0 \mathrm{~V}$ (vs. $\mathrm{Li}^{+} / \mathrm{Li}$ ) at a current density of $200 \mathrm{~mA} \mathrm{~g}^{-1}$. The chargedischarge curves are similar to those of $\alpha-\mathrm{Fe}_{2} \mathrm{O}_{3} /$ carbon composite. ${ }^{31,32}$ The initial discharge capacity is more than $1420 \mathrm{~mA} \mathrm{~h} \mathrm{~g}^{-1}$, which is higher than the theoretical capacity of $\mathrm{Fe}_{2} \mathrm{O}_{3}$ (1007 $\mathrm{mA} \mathrm{h} \mathrm{g}{ }^{-1}$, corresponding to a maximum lithium uptake of $6 \mathrm{Li}$ per $\left.\mathrm{Fe}_{2} \mathrm{O}_{3}\right)$. The extra capacity has been explained as due to the decomposition of electrolyte to form a solid electrolyte interphase (SEI) layer at $0.75 \mathrm{~V} v s . \mathrm{Li}^{+} / \mathrm{Li}^{33}$ or further lithium storage via interfacial reaction due to the charge separation at the metal/ $\mathrm{Li}_{2} \mathrm{O}$ phase boundary. ${ }^{34}$ The reversible capacity is approximately $800 \mathrm{~mA} \mathrm{~h} \mathrm{~g}{ }^{-1}$ with a platform around $1.0 \mathrm{~V}$ versus $\mathrm{Li}^{+} / \mathrm{Li}$. The $\mathrm{d} Q / \mathrm{d} V$ curves are shown in Fig. 7(b). The position of the cathodic peak at $1.0 \mathrm{~V}$ shifted gradually to the left by about $0.1 \mathrm{~V}$, and the intensity of the peak was also decreased from the 2nd cycle to the 200th cycle. This is related to the capacity loss of the displacement reaction and the decomposition of electrolyte. The specific surface area of $\mathrm{Fe}_{2} \mathrm{O}_{3} / \mathrm{RGO}$ composite is $32.1 \mathrm{~m}^{2} \mathrm{~g}^{-1}$, as measured by the 15-point Brunauer-Emmett-Teller (BET) $\mathrm{N}_{2}$ adsorption method. The RGO content in the $\mathrm{Fe}_{2} \mathrm{O}_{3} / \mathrm{RGO}$ was determined by thermogravimetric analysis (TGA) and differential scanning calorimetry (DSC), as shown in Fig. S7, ESI. $\dagger$ The weight loss is $31.7 \%$ from $300{ }^{\circ} \mathrm{C}$ to $550{ }^{\circ} \mathrm{C}$ in air under an exothermic process. This is due to the decomposition of RGO. Therefore, the RGO content in the composite is approximately $32 \mathrm{wt} \%$. The cycling stability is shown in Fig. 8(a). The average coulombic efficiency is around $99 \%$. The capacity stabilized at about $700 \mathrm{~mA} \mathrm{~h} \mathrm{~g}^{-1}$ after 10 cycles, and then the capacity started to increase from the 50th cycle. The capacity reached $852 \mathrm{~mA} \mathrm{~h} \mathrm{~g}^{-1}$ after 200 cycles, showing excellent capacity retention. The capacity increase is possibly related to the 

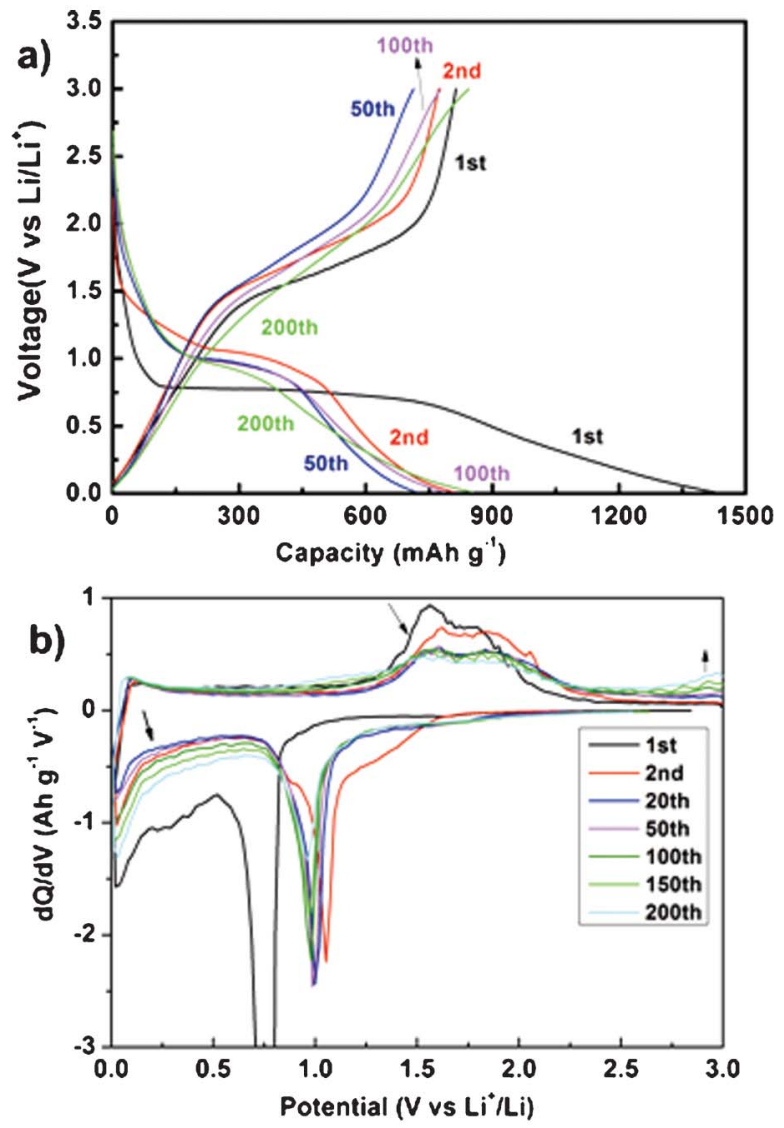

Fig. 7 (a) Charge-discharge curves for selected cycles, and (b) dQ/dV curves for selected cycles.

decomposition of electrolyte. The rate capability was also investigated using a changing rate charge-discharge measurement, as shown in Fig. 8(b). Here, $1 C$ is equal to $1000 \mathrm{~mA} \mathrm{~h}$ $\mathrm{g}^{-1}$. The capacity is $425 \mathrm{~mA} \mathrm{~h} \mathrm{~g}^{-1}$ at the $4 C$ rate, which is about $50 \%$ of the reversible capacity, and the electrode therefore shows good rate capability. Both the good cycling stability and the good rate capability can be attributed to the novel RGOwrapped composite structure, which can buffer the volume changes and maintain good electrical conductivity.

Lithium storage in $\mathrm{Co}_{3} \mathrm{O}_{4} / \mathrm{RGO}$ composite was also investigated and shown in Fig. 9. The charge-discharge curves are similar to those of $\mathrm{Co}_{3} \mathrm{O}_{4}$ /graphene composite. ${ }^{2 b}$ The reversible capacity is approximately $800 \mathrm{~mA} \mathrm{~h} \mathrm{~g}^{-1}$ up to 100 cycles. The binder used here is polyvinylidene difluoride (PVDF), which normally shows much worse cycling stability than sodium carboxymethyl cellulose (CMC) binder. ${ }^{24}$ Therefore, the good cycling stability can be attributed to the novel RGOwrapped composite structure, which can buffer the volume changes.

\section{Conclusions}

Transition metal oxide $\left(\mathrm{Mn}_{3} \mathrm{O}_{4}, \mathrm{Fe}_{2} \mathrm{O}_{3}, \mathrm{Co}_{3} \mathrm{O}_{4}\right.$, and $\left.\mathrm{ZnO}\right)$ and reduced graphene oxide (RGO) composites were successfully
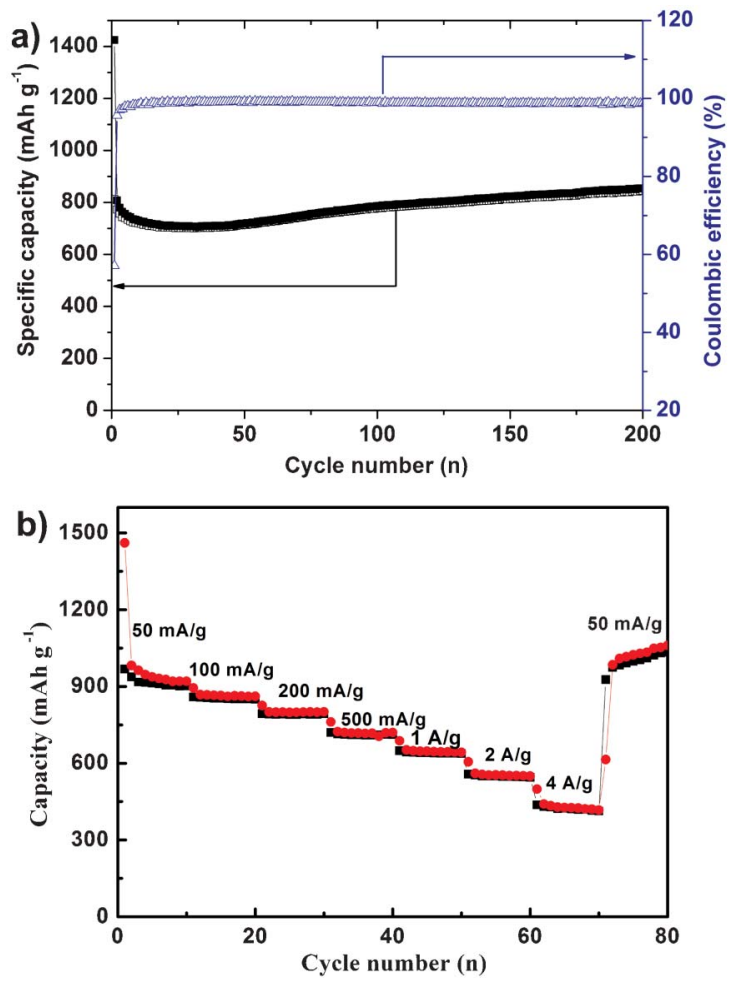

Fig. 8 (a) Cycling life, and (b) charging rate cycling stability of the $\mathrm{Fe}_{2} \mathrm{O}_{3} / \mathrm{RGO}$ composite electrode.
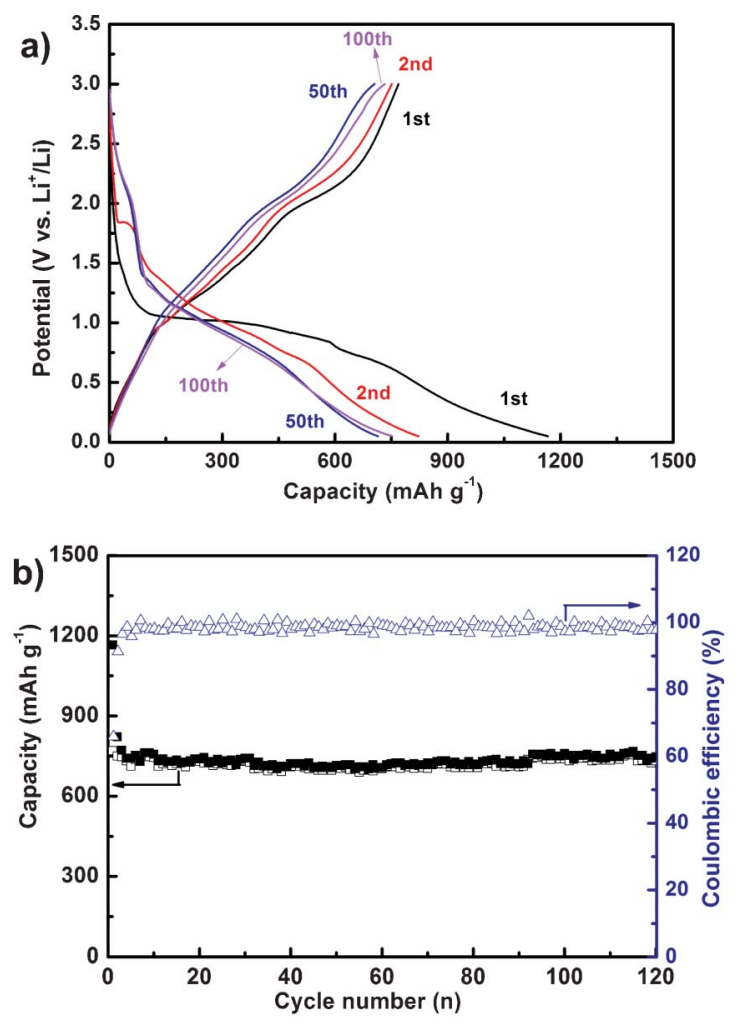

Fig. 9 (a) Charge-discharge curves for selected cycles and (b) cycling stability of the $\mathrm{CO}_{3} \mathrm{O}_{4} / \mathrm{RGO}$ composite electrode. 
synthesized via a hydrothermal method using the direct reaction between the corresponding metal powder and graphene oxide (GO) in water. The metal oxide nanoparticles are wrapped by sheet-like RGO and have a relatively narrow particle size distribution. Good cycling stability can be observed when electrochemically storing lithium in the $\mathrm{Fe}_{2} \mathrm{O}_{3} / \mathrm{RGO}$ (852 $\mathrm{mA} \mathrm{h} \mathrm{g}{ }^{-1}$ up to 200 cycles) and $\mathrm{Co}_{3} \mathrm{O}_{4} / \mathrm{RGO}$ composites ( $800 \mathrm{~mA} \mathrm{~h} \mathrm{~g}{ }^{-1}$ up to 100 cycles). This is attributed to the novel RGO-wrapped composite structure, which can buffer the volume changes and maintain good electrical conductivity. This simple and green method could be easy to scale up for synthesis of metal oxide and graphene composites.

\section{Acknowledgements}

Financial support was provided by the Australian Research Council (ARC) through a Discovery Project (DP110103909) and the ARC Center of Excellence for Electromaterials Science (CE0561616), the National Natural Science Foundation of China (No. 20504026), Shanghai Natural Science Foundation 13ZR1411900, the Shanghai Nanotechnology Promotion Center (No. 11nm0507000), a Shanghai Leading Academic Discipline Project (B502), and a Shanghai Key Laboratory Project (08DZ2230500). The authors also want to thank Dr T. Silver for critical reading of the manuscript.

\section{Notes and references}

1 S. Mao, Z. H. Wen, H. Kim, G. H. Lu, P. Hurley and J. H. Chen, ACS Nano, 2012, 6, 7505.

2 (a) D. H. Wang, D. W. Choi, J. Li, Z. G. Yang, Z. M. Nie, R. Kou, D. H. Hu, C. M. Wang, L. V. Saraf, J. G. Zhang, I. A. Aksay and J. Liu, ACS Nano, 2009, 3, 907; (b) Z. S. Wu, W. C. Ren, Z. Wen, L. B. Gao, J. P. Zhao, Z. P. Chen, G. M. Zhou, F. Li and H. M. Cheng, ACS Nano, 2010, 4, 3187-3194; (c) J. X. Zhu, T. Zhu, X. Z. Zhou, Y. Y. Zhang, X. W. Lou, X. D. Chen, H. Zhang, H. H. Hng and Q. Y. Yan, Nanoscale, 2011, 3, 1084-1089.

3 P. V. Kamat, J. Phys. Chem. Lett., 2011, 2, 242-251.

4 Q. W. Huang, D. W. Zeng, H. Y. Li and C. S. Xie, Nanoscale, 2012, 4, 5651.

5 J. F. Wang, T. Tsuzuki, B. Tang, X. L. Hou, L. Sun and X. G. Wang, ACS Appl. Mater. Interfaces, 2012, 4, 3084.

6 J. K. Liu, H. Q. Cao, J. P. Xiong and Z. Y. Cheng, CrystEngComm, 2012, 14, 5140.

7 X. Wang, L. Song, H. Y. Yang, W. Y. Xing, H. D. Lu and Y. Hu, J. Mater. Chem., 2012, 22, 3426.

8 X. J. Zhu, Y. W. Zhu, S. Murali, M. D. Stoller and R. S. Ruoff, ACS Nano, 2011, 5, 3333.

9 J. W. Lee, A. S. Hall, J. D. Kim and T. E. Mallouk, Chem. Mater., 2012, 24, 1158.

10 T. G. Xu, L. W. Zhang, H. Y. Cheng and Y. F. Zhu, Appl. Catal., B, 2011, 101, 382.

11 P. Bhunia, G. Kim, C. Baik and H. Lee, Chem. Commun., 2012, 48, 9888.
12 J. F. She, H. W. Ma, N. Li and M. X. Ye, Mater. Res. Bull., 2011, 46, 2077.

13 W. B. Yue, Z. Z. Lin, S. H. Jiang and X. J. Yang, J. Mater. Chem., 2012, 22, 16318.

14 (a) Z. J. Fan, W. Kai, J. Yan, T. Wei, L. J. Zhi, J. Feng, Y. M. Ren, L. P. Song and F. Wei, ACS Nano, 2011, 5, 191; (b) Z. J. Fan, K. Wang, T. Wei, J. Yan, L. P. Song and B. Shao, Carbon, 2010, 48, 1670.

15 R. S. Dey, S. Hajra, R. K. Sahu, C. Retna Raj and M. K. Panigrahi, Chem. Commun., 2012, 48, 1787.

16 V. H. Pham, H. D. Pham, T. T. Dang, S. H. Hur, E. J. Kim, B. S. Kong, S. Kim and J. S. Chung, J. Mater. Chem., 2012, 22, 10530.

17 (a) X. G. Mei, H. Q. Zheng and J. Y. Ouyang, J. Mater. Chem., 2012, 22, 9109; (b) X. G. Mei and J. Y. Ouyang, Carbon, 2011, 49, 5389.

18 Y. Z. Liu, Y. F. Li, M. Zhong, Y. G. Yang, Y. F. Wen and M. Z. Wang, J. Mater. Chem., 2011, 21, 15449.

19 (a) W. S. Hummers and R. E. Offeman, J. Am. Chem. Soc., 1958, 80, 1339; (b) Y. X. Xu, H. Bai, G. W. Lu, C. Li and G. Q. Shi, J. Am. Chem. Soc., 2008, 130, 5856.

20 C. Gómez-Navarro, R. T. Weitz, A. M. Bittner, M. Scolari, A. Mews, M. Burghard and K. Kern, Nano Lett., 2007, 7, 3499.

21 S. Stankovich, D. A. Dikin, R. D. Piner, K. A. Kohlhaas, A. Kleinhammes, Y. Jia, Y. Wu, S. T. Nguyen and R. S. Ruoff, Carbon, 2007, 45, 1558.

22 I. K. Moon, J. Lee, R. S. Ruoff and H. Lee, Nat. Commun., 2010, 1, 73.

23 D. Li, M. B. Muller, S. Gilje, R. B. Kaner and G. G. Wallace, Nat. Nanotechnol., 2008, 3, 101.

24 R. Muszynski, B. Seger and P. V. Kamat, J. Phys. Chem. C, 2008, 112, 5263.

25 L. H. Tang, Y. Wang, Y. M. Li, H. B. Feng, J. Lu and J. H. Li, Adv. Funct. Mater., 2009, 19, 2782.

26 D. L. A. De Faria, S. V. Silva and M. T. De Oliveira, J. Raman Spectrosc., 1997, 28, 873.

27 C. C. Hu, Y. T. Wu and K. H. Chang, Chem. Mater., 2008, 20, 2890.

28 V. G. Hadjiev, M. N. Iliev and I. V. Vergilov, J. Phys. C: Solid State Phys., 1988, 21, L199.

29 J. J. Wu and S. C. Liu, J. Phys. Chem. B, 2002, 106, 9546.

30 C. D. Wagner, G. E. Muilenberg, L. E. Davis and J. F. Moulder, Handbook of X-ray photoelectron spectroscopy: A reference book of standard data for use in $X$-ray photoelectron spectroscopy, Physical Electronics Division, PerkinElmer Corp., Eden Prairie, Minn., 1979.

31 S. L. Chou, J. Z. Wang, D. Wexler, K. Konstantinov, C. Zhong, H. K. Liu and S. X. Dou, J. Mater. Chem., 2010, 20, 2092.

32 S. L. Chou, J. Z. Wang, Z. X. Che, H. K. Liu and S. X. Dou, Nanotechnology, 2011, 22, 265401/1.

33 D. Larcher, C. Masquelier, D. Bonnin, Y. Chabre, V. Masson, J. B. Leriche and J. M. Tarascon, J. Electrochem. Soc., 2003, 150, A133.

34 J. Jamnik and J. Maier, Phys. Chem. Chem. Phys., 2003, 5, 5215. 